\title{
Comparison of Cytochrome b Region Among Chinese Painted Quail, Wild-Strain Quail, and White Broiler Chicken Based on PCR-RFLP
} Analysis

\author{
Xiang-Jun SheN ${ }^{1)}$, Hidenori Suzuki ${ }^{2 *}$, Masaoki TsudzukI ${ }^{3)}$, \\ Shin'ichi ITO $^{2)}$ and Takao NAKAMURA ${ }^{2)^{* *}}$ \\ 1) The United Graduate School of Agricultural Science, \\ ${ }^{2)}$ Faculty of Agriculture, Gifu University, Gifu 501-1193 \\ ${ }^{3)}$ Faculty of Applied Biological Science, Hiroshima \\ University, Higashi-Hiroshima 739-8528
}

\begin{abstract}
PCR-RFLP analysis was used to examine 1,075 bp cytochrome $b$ (Cyt b) region of mtDNA in each of 20 birds of Chinese painted quail (Excalfactoria chinensis), wild-strain Japanese quail (Coturnix japonica), and white broiler chicken (Gallus gallus). The total Cyt $\mathrm{b}$ amplicon was digested with 10 restriction endonucleases, and its electrophoretic pattern was investigated. Ten kinds of restriction enzyme digestions were identical among 20 individuals in each of the three species. No variation was observed in the 10 kinds of enzyme digestions among different individuals within the three species investigated. The different specific electrophoretic patterns, haploty pes, and total restriction fragments were observed in each of the three species belonging to the same family Phasianidae. The result representatives the evolutionary genetic characteristics of RFLP of cytochrome $b$ region in the three different species, and indicated the genetic diversity among the three genuses of the family Phasianidae, and genetic identity within each of the species. The result could be used for the identification of different species within family Phasianidae and as a reference of physical map for cytochrome b gene.
\end{abstract}

(Jpn. Poult. Sci., 36 : 287-294, 1999)

Key words : PCR-RFLP, cytochrome b, Excalfactoria chinensis, Coturnix japonica, Gallus gallus

\section{Introduction}

Chinese painted quail (Excalfactoria chinensis) belongs to the order Galliformes, family Phasianidae, and genus Excalfactoria, (Y AmAshinA, 1986). Japanese quail belongs to the same family Phasianidae, a different genus Coturnix (CRAWFORD, 1990). Chicken also belongs to the same family Phasianidae, a different genus Gallus.

Mitochondria play a central role in energy metabolism, amino acid metabolism, fat metabolism, and steroidogenesis (WhitTAKer and DANKs, 1978). The genes present in out-nuclear, i.e. mitochondrial genome, are coding for mitochondrial tRNA, rRNA, and for genes coding for 13 protein genes responsible for oxidative phosphorylation

Received February 19, 1999 Accepted April 8, 1999

* Present address : Kasugai City Office, Kasugai 486-0842

** To whom correspondence should be addressed. 
(OXPHOS) complexes. Cytochrome $\mathrm{b}$ is one of the 13 protein genes encoded by mitochondrial DNA ( $\mathrm{mtDNA}$ ), and it is one of the best known ones of the nine proteins that make up Complex III of the mitochondrial oxidative phosphorylation system (HATEFI, 1985). Mitochondrial Cyt b gene have been used for the identification of meat species in 8 mammal and 4 birds (CHIKUNI et al., 1993). According to recent research reports, the RFLP of mitochondrial DNA has been found to be associated with body weight, egg quality traits, and egg production in chicken (KuHNLEIN et al., 1997 ; KUHNLEIN and ZADWORNY, 1994 ; Li et al., 1998).

PCR-RFLP analysis of Cyt b gene in horse (MARKLUnd et al., 1995) and Japanese quail (SHEN et al., 1998), sequencing analysis of mitochondrial cytochrome b gene in Indian blue quail (YAMASHITA et al., 1998), and similarity phylogenetic relationships in cytochrome $\mathrm{b}$ region among 13 perching bird species (EDWARDS and ARCTANDER, 1997) and among francolins (BLOOMER and CROWE, 1998) have been reported.

No report is available, however, on the PCR-RFLP of Cyt b in Chinese painted quail, wild-strain of Japanese quail, and white broiler chicken.

The purposes of this study are to investigate RFLPs for the cytochrome $b$ region in the Chinese painted quail, Japanese quail, and chicken, and to compare the genetic conformation and diversity among these three species.

\section{Materials and Methods}

Samples. Each of the 20 birds ( 10 males and 10 females) of Chinese painted quail, wild-strain Japanese quail, and white broiler chicken from the University of Osaka Prefecture, National Institute of Animal Industry, and Gifu University, were used in the present study, respectively. The wild-strain of Japanese quail had been captured in Japan and has been maintained as a closed population for some 30 years.

MtDNA preparation. MtDNAs were prepared from the quail livers with the alkaline lysis method as described by TAMURA and Aotsuka (1988), with slight modification. The extracted mtDNA was used as template DNA for use with PCR.

Survey of $m t D N A$ concentration. The mtDNA concentrations of all the samples were measured with a Pharmacia Biotech GeneQuant.

PCR primer. To design PCR primers for the Cyt b region, we compared the published sequences for chickens (DESJARDINS and MoraIs, 1990) and quails (KoRNEGAY et al., 1993), and designed the following two primers :

Forward primer : 5'-CTCCCCCAAACATCTCCGCCTGATGAA-3'

Reverse primer : 5'-GAGTCTTCAGTTTTTGGTTTACAAGAC-3'

$P C R$. Amplification was performed in a $100 \mu l$ solution containing $6.7 \mathrm{mM}$ Tris, 6.7 $\mathrm{mM} \mathrm{MgSO}_{4}, 16 \mathrm{mM}\left(\mathrm{NH}_{4}\right)_{2} \mathrm{SO}_{4}, 10 \mathrm{mM}$ mercaptoethanol, $1 \mathrm{mM}$ dNTP, each of $1 \mu \mathrm{l}$ primers, $50 \mathrm{ng}$ of mtDNA, and 2.5 units of Taq polymerase. Total of 30 cycles were performed with each cycle of the reaction consisted of denaturation for $40 \mathrm{sec}$ at $94^{\circ} \mathrm{C}$, annealing for $45 \mathrm{sec}$ at $55^{\circ} \mathrm{C}$, and extension for $1 \mathrm{~min}$ at $70^{\circ} \mathrm{C}$.

Purification and restriction analysis. PCR products were purified with Centricon (Pharmacia) to remove primers and any impurities. Eight restriction enzymes (AluI, $B s h 1236 \mathrm{I}, B s u$ RI, CfoI, Hin6I, MspI, RsaI, and TaqI) that recognize four base pairs and 
two more that ( $C f r 13 \mathrm{I}$ and $H i n \mathrm{fI}$ ) recognize five base pairs were used in this experiment to cleave the Cyt $b$ region that had been amplified by PCR. The samples treated with restriction endonuclease were purified with phenol-chloroform purification and ethanol extraction.

Electrophoresis. The samples were analyzed by acrylamide gel electrophoresis methods.

Data analysis. The length of restriction fragments was compared with the DNA standards-50-2,000 bp Ladder of BIO-RAD on the acrylamide gel, and band sizes were determined by using computer program Image Master $1 \mathrm{D}$ of Pharmacia Biotech.

\section{Results}

PCR and purification. A DNA band of $1,075 \mathrm{bp}$ obtained using PCR was identificd with $1 \%$ agarose gel electrophoresis. The amplified PCR products of mtDNA were verified with the PCR method using the original two primers, and dot blot hybridization. The products were purified with the Micro Spin column of Pharmacia Biotech (Fig. 1).

Restriction analysis. The size of bands produced by electrophoresis was identified by comparison of standard size markers using graphical methods. The cleavage patterns including band numbers and sizes, are shown in Table 1.

Electrophoretic pattern. In the Chinese painted quail population, each of $4,4,3,3,4$, 2, and 6 cleavage fragments was observed from $A l u \mathrm{I}, B s u \mathrm{RI}, C f o \mathrm{I}, H i n \mathrm{f} 6 \mathrm{I}, R s a \mathrm{I}, C f r 13 \mathrm{I}$, and $\operatorname{HinfI}$, and no cleavage sites were found in the Bsh1236I, MspI, and TaqI digestions. In the wild-strain quail population, each of 3, 5, 2, 2, 4, 2, and 4 cleavage fragments was observed from AluI, BsuRI, CfoI, Hin6I, RsaI, TaqI and HinfI, and no cleavage sites were found in the Bsh1236I, MspI, and Cfr13I digestions. In the white broiler chicken population, each of 4, 2, 2, 3, 2, 2, and 4 cleavage fragments was observed from $B s u$ RI, $C f o \mathrm{I}, \operatorname{Hin} 6 \mathrm{I}, R s a \mathrm{I}, \operatorname{Taq} \mathrm{I}, C f r 13 \mathrm{I}$, and HinfI, and no cleavage sites were found in the $A l u \mathrm{I}$, $B s h 1236$ I, and MspI digestions (Fig. 2). Of the 10 kinds of restriction endonucleases

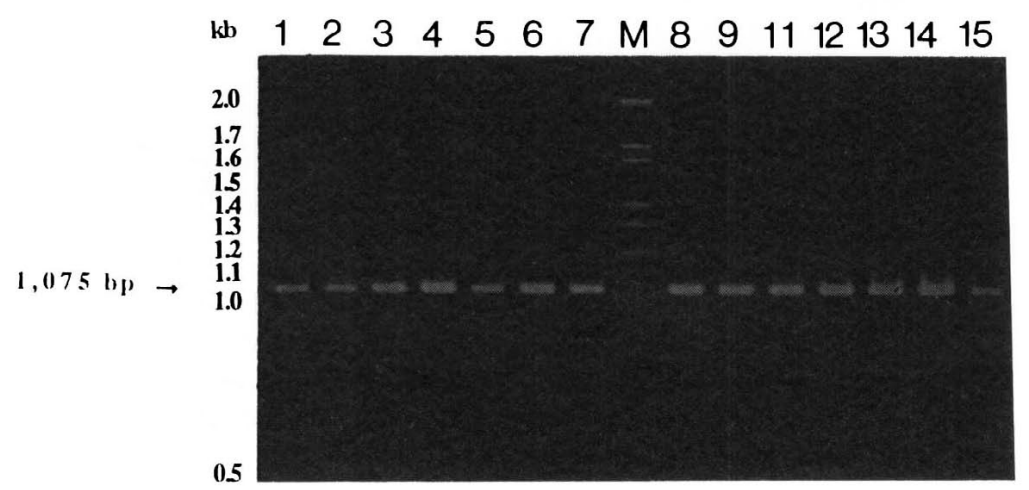

Fig. 1. Agarose gel electrophoretic pattern of $1,075 \mathrm{bp}$ cytochrome b region that was amplified via PCR in Chinese painted quail. Lanes from 1 to 7 are male samples, $\mathrm{m} 1$ to $\mathrm{m}, \mathrm{M}$ is the $100 \mathrm{bp}$ ladder of DNA molecular weigh marker, lanes from 8 to 15 are for female, $f 1$ to $f$, respectively. 
Table 1. The numbers and the sizes of electrophoretic bands of cytochrome $b$ after treatment with ten different restriction endonucleases

\begin{tabular}{cccc}
\hline \hline \multirow{2}{*}{$\begin{array}{c}\text { Restriction } \\
\text { endonuclease }\end{array}$} & \multicolumn{3}{c}{ The size of each fragment (bp) } \\
\cline { 2 - 4 } & Chinese painted quail & $\begin{array}{c}\text { Wild-strain } \\
\text { Japanese quail }\end{array}$ & White brother chicken \\
\hline AluI & $578,202,183,112$ & $430,374,271$ & 1,075 \\
Bsh $1236 \mathrm{I}$ & 1,075 & 1,075 & 1,075 \\
Bs $u$ RI & $481,251,232,111$ & $595,176,147,84,73$ & $641,169,157,108$ \\
CfoI & $701,195,179$ & 824,251 & 880,195 \\
Hin $6 \mathrm{I}$ & $699,194,182$ & 824,251 & 881,194 \\
MspI & 1,075 & 1,075 & 1,075 \\
RsaI & $469,330,170,106$ & $389,293,219,174$ & $586,326,163$ \\
TaqI & 1,075 & 887,188 & 630,445 \\
Cfr $13 \mathrm{I}$ & 642,433 & 1,075 & 727,348 \\
Hinf $\mathrm{fI}$ & $390,295,195,72,67,56$ & $399,308,193,175$ & $419,293,188,175$ \\
\hline
\end{tabular}

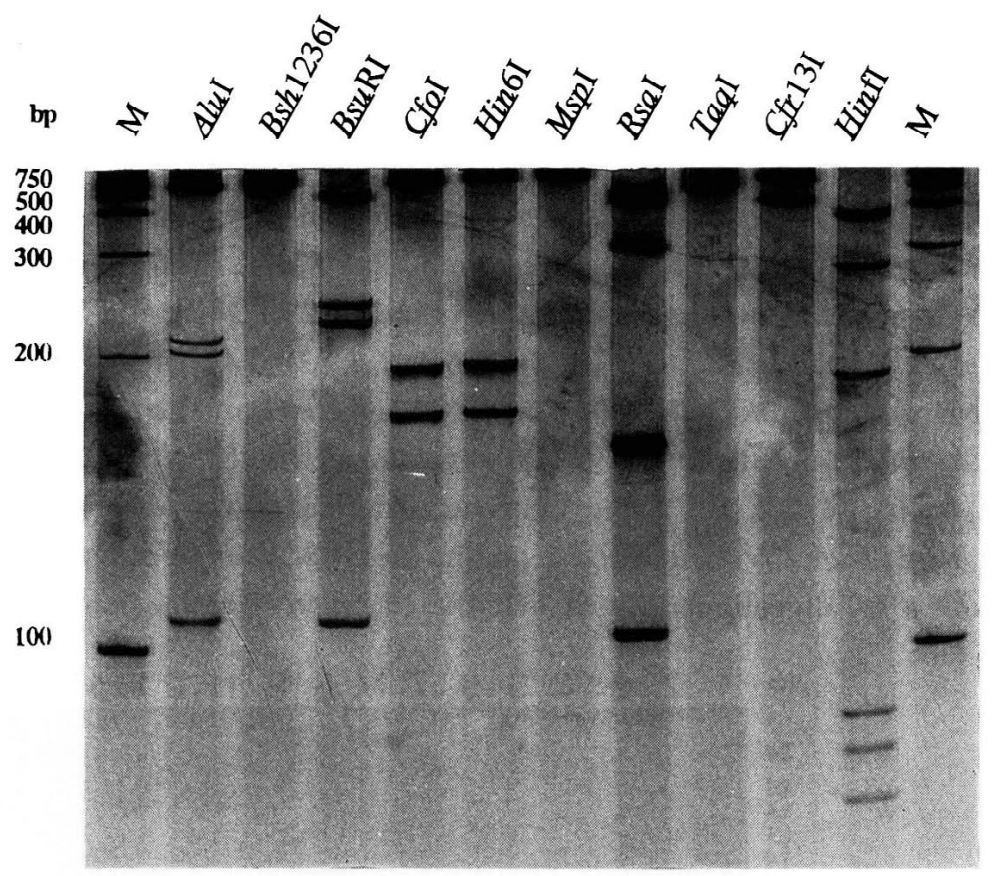

Fig. 2. Acrylamide gel electrophoretic pattern of 1,075 bp cytochrome $b$ region which was digested with 10 kinds of endonucleases in Chinese painted quail. $M$ is the DNA standards $-50-2,000 \mathrm{bp}$ Ladder of BIO-RAD, and its band sizes shown in the Fig. 2 is $100,200,300,400,500$ and 750 bp, respectively.

used in this investigation, the two enzymes $B s h 1236 \mathrm{I}$ and $M s p$ I were not suitable for detecting RFLPs of cytochrome $b$ region in any of the three species in the family Phasianidae.

Restricton fragment comparison. The ten kinds of restriction enzyme digestions 
Table 2. RFLP cytochrome b haplotypes distributed in the Chinese painted quail, wildstrain Japanese quail, and White brother chicken

\begin{tabular}{lcccccccccc}
\hline \multicolumn{1}{c}{ Population } & \multicolumn{7}{c}{$\begin{array}{c}\text { Restriction endonuclease cleavage pattern } \\
\text { (Cleaved fragment number) }\end{array}$} \\
\hline & AluI & $\begin{array}{c}\text { Bsh } \\
\text { 1236 I }\end{array}$ & BsuRI & CfoI & Hin & MspI & RsaI & TaqI & $\begin{array}{c}\text { Cfr } \\
\text { HinfI }\end{array}$ \\
Chinese painted quail & 4 & 1 & 4 & 3 & 3 & 1 & 4 & 1 & 2 & 6 \\
Wild-strain Japanese quail & 3 & 1 & 5 & 2 & 2 & 1 & 4 & 2 & 1 & 4 \\
White broiler chicken & 1 & 1 & 4 & 2 & 2 & 1 & 3 & 2 & 2 & 4 \\
\hline
\end{tabular}

were identical among 20 individuals in each of the three species and no variations were observed among different individuals. The RFLP of Cyt $\mathrm{b}$ region in the three species showed so high specificity that even there was no common fragments shared among the three species populations. Eight of the ten restriction endonuclease except enzymes Bsh1236I and MspI digestions showed specific patterns among the three species belonging to the same family Phasianidae. These restriction enzymes were useful in the identification of individuals among the three species except enzymes Bsh $1236 \mathrm{I}$ and MspI. With the 10 restriction endonucleases treated each of the 29,25 , and 22 total restriction fragments was investigated in the Chinese painted quail, wild-strain quail, and white broiler chicken populations, respectively.

Haplotype. According to the electrophoretic pattern shown in Table 1, the haplotypes were determined in the Chinese painted quail, wild-strain quail, and white broiler populations, as shown in Table 2. Each of the identical haplotypes was investigated among individuals in each species. Each of the specific haplotype patterns was found in the three species populations.

\section{Discussion}

As the results, no variations were observed among individuals within each species from the PCR-RFLP analysis for the Cyt $\mathrm{b}$ region. Our results of finding no genetic variation in the wild type population were in accordance with those of KIMURA and FUJII (1989), who reported on the genetic variability in the wild and domestic Japanese quail populations using 34 enzyme and protein loci. The heterozygosity $(\overline{\mathrm{H}})$ value estimated for the wild quail was significantly lower than that for the domestic quail, and the $F_{\text {st }}$ and the $D$ value obtained didn't show any significant difference among three wild quail populations collected from different localities (KIMURA and FUJII, 1989). It indicated genetic identity of wild quail populations in spite of its different geographical distribution. The wild type population only suffered from mild natural selection, which was not as serious as that caused by artificial selection. The Cyt b gene conformation of the wild type population further inferred that the wild strain quail were still at the original unique wild gene state and without the diversity. The wild strain maintained in the National Institute of Animal Industry of Japan showing it was seriously managed with closed breeding and well reserved as the wild quail model, and maintained the original characteristics of the wild quail possessed.

Chinese painted quail is the smallest species in the family Phasianidae. It 
originated from India and Southeastern area of China (Y AMASHINA, 1986), and had a very short domesticated history. Only a very limited biological research has been performed on Chinese painted quail compared to that of Japanese quail. Until recently it became a laboratory research animal (Tsudzuki, 1994). So the Chinese painted quail may be still at the wild gene state, and no artificial selection affected them, and consequently, the lack of genetic diversity in the Chinese painted quail population is reasonable.

White broiler is the most famous and earliest domesticated meat species chicken in the world. The isogenic Cyt $\mathrm{b}$ gene without variation were also appeared in the White broiler population, hence it implied that white broiler population have been selected and fixed as a purity strain after long period of breeding.

The genus specificity in the family Phasianidae was reflected from the electrophoretic pattern and haplotype pattern. The total numbers of restriction fragments were also different from each other among the genuses. These phenomenon reflected the evolutionary differentiation among the genuses of the family Phasianidae.

Mitochondria are cytoplasmic organelles that generate the aerobically produced energy transfer molecules of eukaryotic cell, which play an important role in the metablisim. The majority of variant amino acid positions are in membrane-spanning domains of the protein, which code for mammalian cytochrome b (IRWIN et al., 1991). Because of its functional importance and structural limitations we might expect variability in cytocherome $\mathrm{b}$ region to be relatively low.

The primer set designed and used in the experiment indicated that these primer sequences are highly conserved regions in cytochrome b gene, and they could be used commonly among different species in the family Phasianidae. The nucleotide sequence homologies of cytochrome $b$ gene of Chinese painted quail (SHEN and NAKAMURA, 1998) showed $88.9 \%$ and $86 \%$ with Japanese quail (KONERGAY et al., 1993) and White Leghorn chicken (DesJardins and MoraIs, 1990). The PCR-RFLP of Cyt b showed that the region in the three species showed so high specificity that there was no common fragments shared among the three species of the family Phasianidae populations. Though there are specificity in Cyt b gene among the different genuses within the family Phasianidae, the genuses possessed the same conserved region, in area of which the primer design is possible for those of common and useful primers at the $\mathrm{Cyt} b$ region shared among different genuses in the Phasianidae.

CHIKUNI et al., (1994) identified the meat species by the mtDNA Cyt b sequences and further described that the method, which depends on the sequence information, is the precise method for determining meat species, however, it requires more time and money, especially for many samples. FEI et al., (1996) identified meat products of cattle, pig, and chicken, using three different sets of primers with PCR methods in the $\mathrm{D}$-loop region. The method of PCR-RFLP of Cyt $\mathrm{b}$ region used in this experiment is easier and more rapid than the sequencing method as far as observation of genetic diversity and identification of species are concerned.

Cyt b-RFLP analysis directly reflects the mtDNA variation in partial sequence base conformation and the gene diversity. The RFLPs of mitochondrial cytochrome 
b region were determined for representatives of the Chinese painted quail, wild-strain Japanese quail, and white broiler chicken. The PCR-RFLP of Cyt b region is a rapid, simple, economical, and reliable method for the identification of the three species within the family Phasianidae, and for investigating genetic diversity among individuals within species.

It would be interesting to investigate the other families in the same order, or other genus in the same family, or other species in the same genus, or other breeds, strains, and populations in the same species using the same methods of PCR-RFLP of Cyt b as shown in this experiment.

\section{Acknowledgement}

The authors are grateful to Dr.M. KIMURA for his critical comment and reading of the manuscript.

\section{References}

Bloomer, P. and Crowe, T.M. (1998) Francolin phylogenetics : molecular, morphobehavioral, and combined evidence. Molecular Phylogenetics and Evolution, 9 : 236-254.

Chikuni, K., Tabata, T., Saito, M. and Monma, M. (1994) Sequencing of mitochondrial cytochrome $\mathrm{b}$ genes for the identification of meat species. Animal Science and Technology, 65 : 571-579.

CRAWFORD, R.D. (1990) Origin and history of poultry species. Part I, In Poultry Breeding and Genetics (Crawford, R.D., ed.) pp. 1-26. Elsevier, Amsterdam, Oxford, New York, Tokyo.

DESJARDINS, P. and MoRAIS, R. (1990) Sequence and gene organization of the chicken mitochondrial genome. Journal of Molecular Biology, 212, 599-634.

Edwards, S.V. and ARCTANDER, P. (1997) Congruence and phylogenetic reanalysis of perching bird cytochrome b sequences. Molecular Phylogenetics and Evolution, $7: 266-271$.

HATEFI, Y. (1985) The mitochondrial electron transport and oxidative phosphorylation system. Annual Review of Biochemistry, 54 : 1015-1069.

KimURA, M. and FUJII, S. (1989) Genetic variability within and between wild and domestic Japanese quail populations. Japanese Poultry Science, 26 : 245-256.

Kornegay, J.R., Kocher, T.D., Williams, L.A. and Wilson, A.C. (1993). Pathway of lysozyme evolution inferred from the sequence of cy tochrome b in birds. Journal of Molecular Biology, $37: 367-379$.

Kuhnlein, U., Ni, L., Weigend, S., Gavora, J.S., Fairful, W. and Zadworny, D. (1997) DNA polymorphisms in the chicken growth hormone gene : response to selection for disease resistance and association with egg production. Animal Genetics, 28 : 116-123.

KuHNLEIN, U. and ZADWORNY, D. (1994) Disease resistance genetics : selection at the DNA level. In proceedings of the 5 th world congress of genetics applied to livestock production. 249-256.

Li, S., Aggery, S.E., Zadworny, D., Fairful, W. and Kuhnlein, U. (1998) Evidence for a genetic variation in the mitochondrial genome affecting traits in white leghorn chickens. The Journal of Heredity, 89 : 222-226.

Marklund, S., Chaudhary, R., Marklund, L., Sandberg, K. and Andersson, L. (1995) Extensive mtDNA diversity in horses revealed by PCR-SSCP analysis. Animal Genetics, 26 : 193-196.

Shen, X-J., KimURA, M., ITO, S. and NAKAMURA, T. (1998) PCR-RFLP analysis of cytochrome b region of mitochondrial DNA in Japanese quail. Japan Poultry Science Association. Proceedings of 6 th Asian pacific poultry congress. 474-475.

Shen, X-J. and Nakamura, T. (1998) Complete cytochrome b sequence of Excalfactoria chinensis. GenBank database (Accession No. AF109217) (Published in sequence).

Tamura, K. and Aotsuka, T. (1988) Rapid isolation method of animal mitochondrial DNA by the alkaline lysis procedure. Biochemical Genetics, $26: 815-819$.

TsudzukI, M. (1994) Excalfactoria quail as a new laboratory research animal. Poultry Science, 73 : 
763-768.

WhitTAKer, P.A. and DANKs, S.M. (1978) Mitochondria : structure, function and assembly. Longman, New York.

Yamashina, Y. (1986) A world list of birds with Japanese names. Daigaku-Shorin C., Tokyo.

Yamashita, H. Sekiguchi, Y. Uehara, Y. Shibata, T. (1998) Sequence analysis of mitochondrial cytocrome b gene in Indian blue quail. Japan Poultry Science Association. Proceedings of 6 th Asian pacific poultry congress. 476-477.

\section{ヒメウズラ，野生系ウズラとニワトリ白色ブロイラー間の シトクローム b 領域における PCR-RFLP 解析}

沈 相俊 $^{1)} \cdot$ 鈴木后典 $^{2) *} \cdot$ 都築政起 $^{3)} \cdot$ 伊藤慎一 ${ }^{2)} \cdot$ 中村孝雄 ${ }^{2)}$

1) 岐皁大学連合農学研究科,

2) 岥皁大学農学部, 岥阜市 501-1193

${ }^{3)}$ 広島大学生物生産学部, 東広島市 739-8528

* 現住所 : 春日井市役所，春日井市 486-0842

ヒメウズラ（ヒメウズラ属），野生系ウズラ（ウズラ 属）ならびにニワトリ白色ブロイラー（ヤケイ属一） 各々 20 羽を供試し，PCR-RFLPにより，ミトコンドリ アDNA（mtDNA）の 1,075 bpのシトクロームb （Cytb）領域の制限酵素断片長多型解析を行った。PCR により増幅した全ての Cytb 領域を，10 種類の制限酵素 で処理し，アクリルアミド電気泳動法により泳動パター ンを観察した。

その結果, 10 種類の制限酵素の泳動パターンはそれ ぞれ同一種内においては同じ泳動像を示し，個体変異は 見出されなかった。同じキジ科の 3 種類の違う属の集団 （ヒメウズラ, 野生系ウズラおよび白色ブロイラー）間に
は異なる電気泳動パターン，八プロタイプならびに制限 フラグメント数が観察され，ヒメウズラ，野生系ウズラ および白色ブロイラーの各種内における Cytb 領域の PCR-RFLP 特徴とキジ科内の異なる属間の遺伝的変異 性，ならびに各種内の遺伝的同一性を表した。

本研究結果は, キジ科の属間識別とキジ科の mtDNA の Cytb 遺伝子の物理的地図として利用できることが示 唆された。

（家禽会誌，36:287-294, 1999）

キーワード : PCR-RFLP, シトクロームb, ヒメウズ ラ, 野生系ウズラ, 白色ブロイラー 